\title{
The Implementation of Improving Creativity and Innovativity of Cimahi Municipality's Human Resource Policy
}

\author{
I. Jahidi \\ LPK Ariyanti, Bandung, INDONESIA \\ A. Budiati \\ Universitas Sultan Ageng Tirtayasa \\ Serang, Banten, INDONESIA \\ ayoekomara@gmail.com
}

\author{
D. Indah \\ Universitas Langlangbuana \\ Bandung, INDONESIA
}

\begin{abstract}
Cimahi Municipality is a relatively big municipality with twelve million population at West Java Indonesia. This municipality has visions, missions and aims in improving creativeness and innovativeness its human resource to improve their local revenue. However, there are obstacles in the implementation of improving creativity and innovatively of Cimahi municipality's human resources policy, namely unsustainable training programs, lack of capacity of loans, lack of quality of human resources, lack of infrastructure, and lack of marketing. This paper's aim is to analyses the implementation of improving innovativeness and creativity in human resource policy in Cimahi Municipality, Indonesia. The writer argues that the implementation of improving creativity and innovatively of Cimahi Municipality's human resources should be based on communication between government and its people, the quality of human resources, and leaders' commitment, honesty and democratic value and bureaucratic structure. This research uses a qualitative approach and descriptive analysis method. The writer uses a literature review technique to analyses data and information in this research. The results of this research are communication between government and it's society needs to be improved by conducting focus group discussion and workshops in improving creativity and innovatively in local products. There is an urgently need of strategic planning in conducting training that should be based on local human resource needs, restructuring standard operating procedure of local government that handling these issues. The implication of this research is providing strategic solution in improving creativity and innovatively of human resource policy at Cimahi Municipality, Indonesia.
\end{abstract}

Keywords- innovative and creative regulation, implementation, cimahi municipality

\section{INTRODUCTION}

Innovation and creativity are very important factors in this era even for a government. Those factors can become a strategic key successful factors in improving a government to solve their problems in delivering public service. Cimahi's society has innovation and creativity in four categories, namely: food and beverages, crafts, textiles and information technology.
Cimahi municipality has owned innovative volunteering program since March 2012. It also has networking on entrepreneurships and Information technology program. However, the implementation of Cimahi Municipality Regulation No. 6 Year 2010 about the implementation of human resource arts Cimahi Municipality is still ineffective. For example, there is unsustainable training programs, lack of capacity of loans, lack of quality of human resources, lack of infrastructure, and lack of marketing. For example, on 19-20 July 2011, there were technopreneur camp. It is an event to enhance new and young entrepreneur that work with Information Technology. There were 34 young entrepreneur and it was divided into 13 groups from Cimahi Creative Association. Types businesses are animation, movies, multimedia and information technology. However, that event is inconsistent occurs, hence the benefits are still limited.

Based on the Cimahi Municipality Regulation No. 6 Year 2010 part 5, namely to achieve Cimahi's creative and independent situation then improving its human resources becomes government, entrepreneur and Cimahi's society responsibility. However, cooperation and coordination amongst Cimahi's government, businessmen and society to enhance Cimahi's creative and independent city are still need to be improved.

On the same regulation, part 5-(4), Cimahi's society dynamically should actualizing themselves into productive, independent, skillful, productive, creative and innovative. Therefore, there is a need to enhance programs to improve Cimahi's human resource become more creative and innovative.

\section{MethodS}

This paper uses descriptive analysis method and qualitative approach. The writers analysis data and information based on facts and finding about related topic. The main theory that is used is from Edward III about policy implementation. Other theories is for supporting writers opinion and analysis. Literature review is used to analyses data and information regarding the topic. Finally, findings are gained by analyzing that data and information, furthermore the writer also conduct check 
and recheck with other source of information such as current news, journals and Cimahi's people that has local business.

\section{THE IMPLEMENTATION OF INNOVATIVENESS AND CREATIVITY AT CIMAHI MUNICIPALITY'S HUMAN RESOURCE}

Policy is government's actions to achieve its aims and goals. As Van Meter and Van Horn [9] state, policy implementation is actions that is conducted by government or bureaucrats to achieve their policies' objectives. Whereas the importance of policy implementation is stated by Udoji [27] as: "the execution of policies is important if not more important than policy making'. Furthermore, the relationship between policy implementation and public's need is state by Shafritz and Russel [26]:

"Implementation is the process of putting a government program into effects; it is the total process of translating a legal mandate, whether an executive order or an enacted statute into appropriate program directives and structures that provide services or creatives goods".

Meaning, there are actions that are conducted by the bureaucrats to achieve the government's objectives. Those actions are formed into programs and has stages, output or decisions, for example by providing public services. As Mazmanian and Sabatier [16] state:

Implementation is carrying out of a basic policy decision, usually incorporated in a statute but which can also take the form of important executive orders or court decision. Ideally that decisions identifies the problem(s) to be addressed, stimulate(s) to be pursued, and in a variety of ways, "structures" the implementation process. The process normally runs through a number of stages beginning with passage of the basic statute, followed by the policy outputs (decisions) the actual impact both intended and unintended of those outputs, the perceived impact of agency decisions, and finally, important revisions for attempted revisions in the basic statute.

There are three important activities in the policy implementation according to Jones [10], namely:

1. Organization; The establishment or rearrangement of resources, units, and methods for putting a program into effect

2. Interpretation;The translation of program language (often contained in a statue) into acceptable and feasible plans and directives

3. Application; The routine provision of services, payment or other agreed-upon program objectives or instruments.

However, at Cimahi Municipality that theory cannot be used due to lack of information about communication issue. Cimahi municipality that has home industries in selling snacks need more its government aids, especially in improving creativity and innovation in packaging, new marketing strategies (lack of e-commerce) and diversification in flavor and shapes of snacks. Furthermore, Cimahi municipality government only use one way communication, meaning they implement its policy not based on people's need. There is still lack of bottom up communication. Therefore, there is still lack of creativity and innovativeness.

At Agenda setting stage, problems are defined. However, every problems cannot be formulated into policies. Some of the problems are formulated into functional activities. The policies are made for persuasive actions. For example, at Cimahi municipality in its commerce office, only Regulation No. 6 Year 2010 that regulate human resource at Cimahi Municipality, including about its innovative and creativity.

According to Edward III [5]:” Policy implementation is the stage of policy making between the establishment of a policy and the consequences of the policy for the people whom it affects". While Grindle (1980:6) at Tachjan [26] state: "implementation a general process of administrative action that can be investigated at specific program level." Therefore, policy implementation is one step after one regulation is enacted. On the broader point of view, implementation has a meaning to conduct a regulation where actors, organization, procedure and technique work together to achieve their objectives or programs.

Logically, implementation is a top down process, while policy formulation is a bottom up process. That bottom up process should be based on people's need. Therefore, in the case of Cimahi municipality, innovativeness and creativity have lack on implementation due to the type of process of formulation process, namely top down. The policy and its implementation are bad due to the type of the process, namely top down. It should be bottom up process in the formulation process.

Hoogwood\&Lewis A.G [6] argue that implementation: "is seen essentially as a technical or managerial problems". Meaning there are technical and management aspects in the organization to achieve goals. Furthermore, Mazmanian and Sabatier [16] state that the success of one regulation's implementation is being affected by autonomy to conduct those works. In general, policy implementation can be drawn is as follow in figure 1. Based on that theory by Edward III, implementation should be based on four integrated factors, namely: communication, resources, attitudes or disposition and bureaucratic structure.

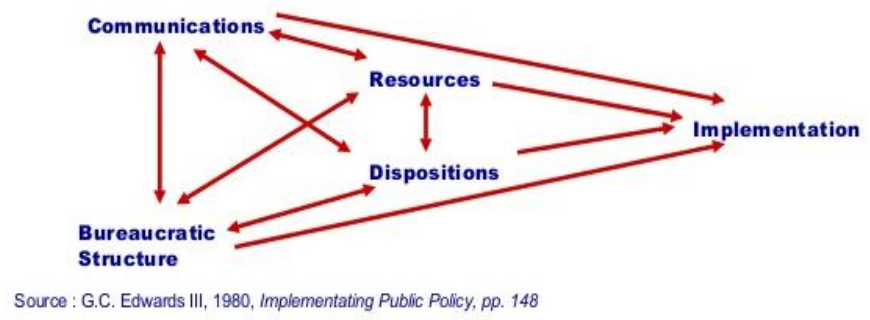

Fig. 1. Policy Implementation Factors by Edward III

\section{A. Communication}

The success of an implementation is also meaning that the implementer know what should be done. All objectives and goals of the regulation or programs should be communicate to the people. Therefore, distortion of the communication process can be eliminated. If the objective and goals are not clear enough, or even the audience or the people do not understand at all about its goals and 
objectives, then ineffective implementation can be occurred.

Communication process is occurred one direct only, meaning only from the local government office to the local business actors. Communication's contents are regulation in managing home industries and training for local business only. There are lack of evaluation and monitoring business by the local government, lack of continuity in training program - not based on businessman needs-, lack of capital aids and lack of marketing events for local products.

\section{B. Resources}

Even though the content of the policy already been communicated clearly and consistent, but if there is lack of good quality in human resource, then ineffective implementation will be occurred. Other resource that also important is financial resource. Lack of financial resource can cause into ineffective implementation. Without resource, policy implementation only a planning issue or a document.

There is lack of good quality human resources in improving the quality of local business, in product and marketing. For example, for snack industries, there is still a need of good quality human resources in making diversity in packaging and marketing their snack products.

There is also lack of financial resource in home industry at Cimahi municipality. There is no financial aid program from the local government. The local business should sell their land, house or borrowing from their relatives.

\section{Disposition or attitude}

Disposition or attitude is a character that own by the implementer. Namely, commitment, honesty and democratic value. If the implementer has good attitude, then he or she can conduct the policy well or policy can be implemented effectively. At Cimahi municipality, especially at commerce office, the office that has authority to organize and manage its human resource has lack of committed leader that focus on programs which can enhance innovative and creative actions.

\section{Bureaucratic Structure}

Bureaucratic structure also has significant role in enhancing good implementation of a policy. One aspect of it is standard operating procedure (SOP). SOP becomes a guideline to all implementers to implement the policy. Moreover, long organization structure can cause ineffective implementation. Due to weakening controlling process and can cause red-taping activity due to complicated bureaucratic.

Cimahi Municipality has a commerce office to implement human resource policy in enhancing creativity and innovativeness of Cimahi's people. However, they do not have a SOP to implement their programs. Lack of integrated training process and lack of good strategic planning process in training process cause ineffective innovativeness and creativity on local businessmen. For example, after one training in mastering computer to create e-commerce, the businessmen can not use the skill due to lack of aid in posting it through the internet. There is no aid in buying or renting domain for posting their business through the internet. Meaning there is lack of training in marketing their product through e-commerce.

\section{CONCLUSIONS}

Communication, resources, attitude and bureaucratic structure are not panacea of good implementation. However in the activity to enhance creativity and innovativeness of Cimahi Municipality's human resources, those four factors need to be enhances. The implementation of improving creativity and innovatively of Cimahi Municipality's human resources should be based on communication between government and its people, the quality of human resources, and leaders' commitment, honesty and democratic value and bureaucratic structure. Therefore, there is a need in improving it by conducting focus group discussion and workshops in improving creativity and innovatively in local products.

There is an urgently need of strategic planning in conducting training that should be based on local human resource needs, restructuring standard operating procedure of local government that handling these issues. Communication between government and it's society needs to be improved by conducting focus group discussion and workshops in improving creativity and innovatively in local products, continue and an integrated training especially in innovative and creative marketing technique, better standard operating procedure in gaining business license and public service delivery, leader's commitment, honesty and democratic leader need to be enhanced, especially in gaining capital for local business.

\section{REFERENCES}

[1] Charlen O.Jones.1991 “ Pengantar Kebijakan Publik”.Jakarta, Rajawali.

[2] Creswell, John W. 2002. Research Design: Qualitative and Quantitative Approach. Uk New Delhi-California: Sage Publications

[3] Daniel, Muhammad dkk, 1998 Kajian Kebutuhan Rusun Sederhana dan Persepsi Pengembang Swasta dalam Pembangunannya di Kotamadya DT II Bandung.

[4] Daniels T. 1998. The Struggle to Manage Growth in the Metropolitan Fringe di dalamPable B dan Mc. Cledon B. editor Revolutionary ideasin planning.

[5] Edward III, George C. 1980. "Implementing Public Policy". Congressional Quarterly Inc, USA

[6] Grindle, M.S. 1980. Politics and Policy Implementation the Third World. New Jersey: Princeton University Press.

[7] Handayaningrat, Soewarno, 1983. Pengantar Studi Ilmu Administrasi dan Manajemen. Jakarta.GunungAgung

[8] Handoko, T.Hani, 2003. Manajemen, Edisi kedua, Badan Penerbit Fakultas Ekonomi, Yogyakarta:Penerbit Salemba Empat

[9] [9] Islami, Irfan, 1995 "Prinsip-Prinsip Perumusan Kebijakan Negara”, Jakarta: Sinar Grafika.

[10] .Jones. Charles, 1991 “ Pengantar Kebijakan Publik”.,Jakarta, Rajawali

[11] ................., 1994 “ Pengantar kebijakan Publik”.,Jakarta: PT Raja Gra[pindo Persada.

[12] [Korten, David C dan Syahrir, 1980 "Pembangunan berdimensi Kerakyatan, Jakarta: Yayasan Obor Indonesia

[13] Kusumanegara, Solahudin, 2010. “ Model dan aktor dalam Proses kebijakan publik”., Yogyakarta: Gava Media

[14] Kelly E.D. 1993. Managing Community Growth Policies, Techniques and Impact.Wesport Connecticut: Praeger

[15] Lester James O and Joseph Stewards Jr, 2000. "Public policy an Evolutionary Approach”, Belmont. CA:Wards Worth 
[16] Mazmanian DA and Paul A Sabatier, 1983. “Implementation and public policy”., London scot, Foresman and Company.

[17] Malcon L Goggin, 1990. "Implementation Theory and Practice"., Toward AThird G.

[18] Miles, Mathew B \& Michael Huberman. 1992. Analisis Data Kualitatif :BukuSumbertentangMetode-metodeBaru. AlihbahasaTjetjepRohendi Effendi. Jakarta: UI Press.

[19] MoleongLexi. J.1998. MetodePenelitianKualitatif.Cetakanke Sembilan, Bandung: PT RemajaRosdakarya

[20] Nugroho, Riant, 2009. "Public Policy” Jakarta: PT Gramedia.

[21] Osborne, David and Ted Gaebler. 1992. Reinventing Government, How The Entrepreneurial Spirit is Transforming The Public Sector.Massachusett: Addison Wesley Publishing Company.

[22] Ripley, Rendal B and Grace A. Franklin, 1986., "Policy Implementation and Bureaucracy second edition", The Darcey Press, Chicago

[23] Rosenbloom, David H. and Kravchuck, Roberts S. 2005."Public Administration: Understanding Management, Politics, and Law on The Public Sector (Sixth)" Edition. New York : McGraw-Hill.

[24] Strauss, Anselm and Corbin Juliet. 1990. Basic of Qualitative Research, Techniques and procedures for Developing Grounded Theory. Sage Publication, International.

[25] Sugiyono. 2008. MetodePenelitianSosial.: PendekatanKuantitatif, Kualitatif, $R \& D$, Bandung; Alfabeth

[26] Tachyan, 2008. "Implementasi Kebijakan publik”., Bandung, Percetakan Truen RTH,

[27] Udoji, Chief, Jo, 1981. “The Afircan Public Servant as a public Maker, Public policy in Africa, Africa Association For PA and Management"., Adelis Abeba.

[28] Terry, G.R, 1977 "Principle of Management”. Third Edition Illinois: Richard D.irwin, Inc

[29] Turner, John F.C 1991 Housing by People. London.Marion Boyars.

[30] Van Meter Donald S and Van Carl Horn, 1975 "The policy Implementation Proces:A Conceptual Framework, Administration and Soviet, $6: 445-488$

[31] Wahab, Solichin abdul, 1997. “Analisis Kebijaksanaan dari Refoemasi ke Implementasi Kebijaksanaan Negara”., Edisi kedua, jakarta: Bumi aksara 